\title{
The Arabidopsis NST3/SND1 promoter is active in secondary woody tissue in poplar
}

\author{
Naoki Takata ${ }^{1}$ (i) $\cdot$ Shingo Sakamoto $^{2} \cdot$ Nobutaka Mitsuda $^{2} \cdot$ Toru Taniguchi $^{1,3}$
}

Received: 1 February 2017 / Accepted: 31 March 2017/Published online: 18 April 2017

(C) The Japan Wood Research Society 2017

\begin{abstract}
Wood biomass is one of the promising future materials for biofuels with no competing food uses. However, the higher cost to produce bioethanol from wood feedstocks is regarded as a priority issue. Genetic engineering techniques have been proposed to enhance the quality and quantity of wood materials to overcome the cost problem. Although many genetically engineered trees with applicable traits such as low lignin, a high syringyl to guaiacyl ratio and high cellulose content are generated, ectopic expression of an effector gene under a constitutive promoter can sometimes induce untoward side effects on plant growth and development. Our recent study demonstrated that AtNST3/SND1 promoter of Arabidopsis thaliana is a candidate tool for driving a potent activator to enhance wood biomass production in poplar without any growth retardation. However, the tissue- and cell-dependent activity of the promoter remains to be elucidated. In the present study, we generated transgenic poplar expressing AtNST3/SND1promoter::GUS to examine in detail the activity of the AtNST3/SND1 promoter. Histochemical analysis revealed that the promoter was predominantly active in secondary woody tissue. Our result indicates that the AtNST3/SND1 promoter is an option for expressing an effector gene to modify secondary cell wall components and wood biomass.
\end{abstract}

Naoki Takata

naokitakata@affrc.go.jp

1 Forest Bio-Research Center, Forestry and Forest Products Research Institute, Hitachi, Ibaraki 319-1301, Japan

2 Bioproduction Research Institute, National Institute of Advanced Industrial Science and Technology, Tsukuba, Ibaraki 305-8566, Japan

3 Forest Tree Breeding Center, Forestry and Forest Products Research Institute, Hitachi, Ibaraki 319-1301, Japan
Keywords NST3/SND1 $\cdot$ Secondary wood $\cdot$ Xylem Promoter · Poplar

\section{Introduction}

Forest trees produce large amounts of lignocellulose, which is regarded as a renewable and cost-effective resource for bioenergy and industry. Wood biomass is expected to be one of the next-generation materials for biofuels since current bioethanol feedstocks such as corn and sugarcane compete with human food demands. Bioethanol produced from wood lignocellulose, however, would be more costly than that from food crops [1]. To reduce the cost of biofuel conversion, one goal is to modify and enhance the quality and quantity of wood materials using transgenic technology. Saccharification efficiency and ethanol production, for example, are gained in genetically engineered poplar, which shows lower lignin content [2, 3], an increased syringyl/guaiacyl (S/G) ratio in lignin [4], and modification of chemical linkages in lignin [5]. In addition, secondary cell walls, which represent a large part of wood biomass, are reinforced by introducing a transcriptional factor and sucrose catalytic enzyme into poplar [6-8]. In spite of many applicable successes, some studies report that ectopic expression of an effector gene under a constitutive promoter such as the cauliflower mosaic virus $35 \mathrm{~S}$ promoter causes unexpected and negative effects on plant growth and development $[7,9,10]$. Use of a tissue-specific promoter to limit effector expression to appropriate cells and tissues is a solution designed to reduce the untoward side effects.

NAC SECONDARY WALL THICKENING-PROMOTING FACTOR3/SECONDARY WALL-ASSOCIATED NACDOMAIN PROTEIN 1 (NST3/SNDI) and NSTl are key 
regulators of secondary cell wall formation in xylem fiber cells in Arabidopsis thaliana [11, 12]. The genes are members of the VNS (VASCULAR-RELATED NACDOMAIN (VND)-, NST/SND- and SOMBRERO (SMB)-related proteins) family and redundantly control secondary wall thickening in woody tissues. The double knockout mutant $n s t 1$ nst3/sndl is deficient in secondary wall of fiber cells, although the single mutants do not show a drastic phenotype affecting cell wall formation [12]. The NST/ $S N D$ genes are highly expressed in xylem fibers of the inflorescence stem in $A$. thaliana $[11,12]$. The xylem-dependent expression pattern is more specific to NST3/SND1 than NST1 since NST1 is expressed to some extent in aboveground tissues such as flowers and leaves. The AtNST3/SND1 promoter, showing woody tissue-specific activity, is a powerful tool for studying the biological process of wood-fiber development and the molecular function of genes that control cell wall formation in $A$. thaliana [13].

We recently enhanced wood biomass production in poplar without any growth retardation using a gene construct containing the AtNST3/SND1 promoter to drive an AtNST3/SND1 homologue in Oryza sativa [14]. However, the tissue- and cell-dependent activity of AtNST3/SNDI promoter remains unclear in poplar. In this study, we generated transgenic hybrid poplar carrying $\beta$-glucuronidase (GUS) driven by the AtNST3/SND1 promoter to investigate in detail the tissue- and cell-dependent activity of the promoter in woody perennial poplar. Histochemical GUS assay clarified that the promoter showed a secondary woody tissue-dependent expression pattern. This result indicates that the AtNST3/SND1 promoter is a promising tool to modify secondary cell wall components and biomass of wood materials through transgenic technology.

\section{Materials and methods}

\section{Plant material and generation of transgenic plants}

Sterile rooted cuttings of Populus tremula $\times$ Populus tremuloides (wild-type clone T89) were cultured in $0.5 \times$ Murashige and Skoog medium ( $\mathrm{pH}$ 5.7) containing $0.8 \%(\mathrm{w} / \mathrm{v})$ agar at $25^{\circ} \mathrm{C}$ under a cycle of 16 -h light $\left(50 \mu \mathrm{mol} \mathrm{m}{ }^{-2} \mathrm{~s}^{-1}\right) / 8$-h dark. Transgenic poplar was generated with the expression binary vector pBCKK-AtNST3/ SND1pro::GUS, by Agrobacterium-mediated transformation $[12,15]$. The binary vector harbors a 3028-bp region upstream of the start codon of AtNST3/SND1 (Gene ID At1g32770). Genomic DNA was extracted by the simple method of the KAPA3G Plant PCR Kit (Kapa Biosystems, Wilmington, MA USA) from leaves of transgenic poplar. PCR was performed by a KAPA3G plant DNA polymerase

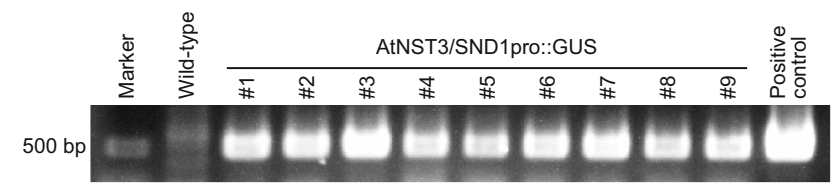

Fig. 1 Generation of transgenic poplar events expressing AtNST3/ SND1pro::GUS. The expression gene cassette was amplified as a 554-bp PCR product from genomic DNA of transgenic poplar

according to the manufacturer's instructions using the primer pair 5'-CTATGTCTCGTCGAGTCCTACCACC-3' and $5^{\prime}$-TCCTGATTATTGACCCACACTTTG- ${ }^{\prime}$. Transformants were potted to soil mix (3:1 fertilized peat moss:vermiculite, $\mathrm{v} / \mathrm{v}$ ) and grown at $20^{\circ} \mathrm{C}$ under long-day conditions (18-h light at $200 \mu \mathrm{mol} \mathrm{m} \mathrm{m}^{-2} \mathrm{~s}^{-1} / 6$-h dark).

\section{Histochemical assays}

Histochemical GUS assays were performed as described by Takata and Taniguchi [15]. Plant tissues such as leaves, stems and roots were harvested from transformants growing for 32 days in soil mix and fixed in cold $90 \%$ acetone for $30 \mathrm{~min}$. Tissues were washed with $50 \mathrm{mM}$ sodium phosphate $(\mathrm{pH}$ 7.0) and then incubated in GUS staining solution [50 mM sodium phosphate ( $\mathrm{pH} 7.0), 0.5 \mathrm{mg} \mathrm{ml}^{-1}$ 5-bromo-4-chloro-3-indolyl- $\beta$-D-glucuronic acid, $0.5 \mathrm{mM}$ potassium ferrocyanide, $0.5 \mathrm{mM}$ potassium ferricyanide, $0.1 \%$ Triton X-100] at $37{ }^{\circ} \mathrm{C}$ for $16 \mathrm{~h}$. Samples postfixed in $2.5 \%(\mathrm{v} / \mathrm{v})$ glutaraldehyde in $50 \mathrm{mM}$ sodium phosphate $(\mathrm{pH} 7.0)$ were bleached in ethanol:acetic acid $(6: 1, \mathrm{v} / \mathrm{v})$ for leaf blades and $70 \%$ ethanol for leaf veins, petioles, stems and roots. Leaf blades were cleared with chloral hydrate/ glycerol solution. Other tissues were infiltrated through a series of $25,33,50,66,75$, and $100 \% 2.3 \mathrm{M}$ sucrose in $100 \mathrm{mM}$ sodium phosphate $(\mathrm{pH} 7.0)$. Leaves and stems were embedded in SCEM-L1 mounting medium (Leica, Solms, Germany) and frozen in liquid nitrogen-cooled hexane. Cryosections of $50 \mu \mathrm{m}$ were cut using a Leica CM3050 S cryomicrotome (Leica). Roots were sectioned at a thickness of $80 \mu \mathrm{m}$ using a vibratome (Dosaka EM, Kyoto, Japan). Samples were imaged by a Leica MZ FLIII stereomicroscope and a Leica DMR microscope (Leica).

\section{Results and discussion}

Nine transgenic events were generated by Agrobacteriummediated transformation (Fig. 1), and plants from two independent events, \#1 and \#3, were assayed histochemically. Figure 2 shows the GUS staining pattern of these transgenic poplar plants in the leaf blade (Fig. 2d, 1), leaf main vein (Fig. 2e, m), petiole (Fig. 2f, n), young stem (Fig. 2c, k), mature stem (Fig. 2a, b, i, j) and root (Fig. 2g, 
Fig. 2 Histochemical GUS analysis in two independent transgenic events (\#1, a-h; \#3, $\mathbf{i}-\mathbf{p})$. The images are from mature stem $(\mathbf{a}, \mathbf{b}, \mathbf{i}, \mathbf{j})$, young stem $(\mathbf{c}, \mathbf{k})$, leaf blade $(\mathbf{d}, \mathbf{l})$, a cross section of the main vein $(\mathbf{e}, \mathbf{m})$, a cross section of the petiole $(\mathbf{f}, \mathbf{n})$, root $(\mathbf{g}, \mathbf{o})$ and a cross section of the root $(\mathbf{h}, \mathbf{p})$. $C Z$ cambial zone, $F$ xylem fiber, $P F$ phloem fiber, $P h$ phloem, $P i$ pith, $P X$ primary xylem, $R$ ray parenchyma cell, $S X$ secondary xylem, $X y$ xylem, $V$ vessel element. Bars indicate $1 \mathrm{~cm}(\mathrm{~g}$, o), $100 \mu \mathrm{m}(\mathbf{a}, \mathbf{c}-\mathbf{f}, \mathbf{h}, \mathbf{i}, \mathbf{k}-\mathbf{n}$, p) and $10 \mu \mathrm{m}(\mathbf{b}, \mathbf{j})$ (a)

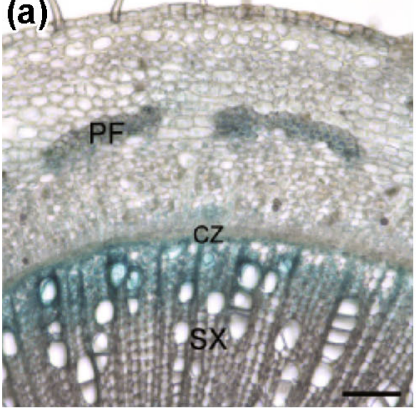

(b)
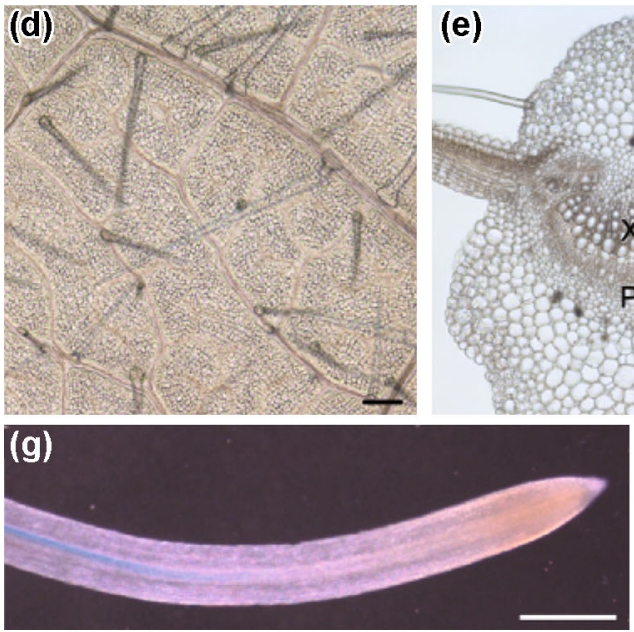

(i)

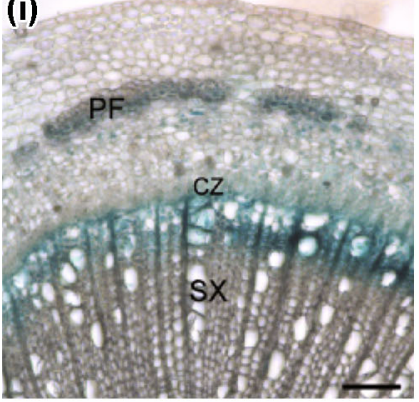

(I)
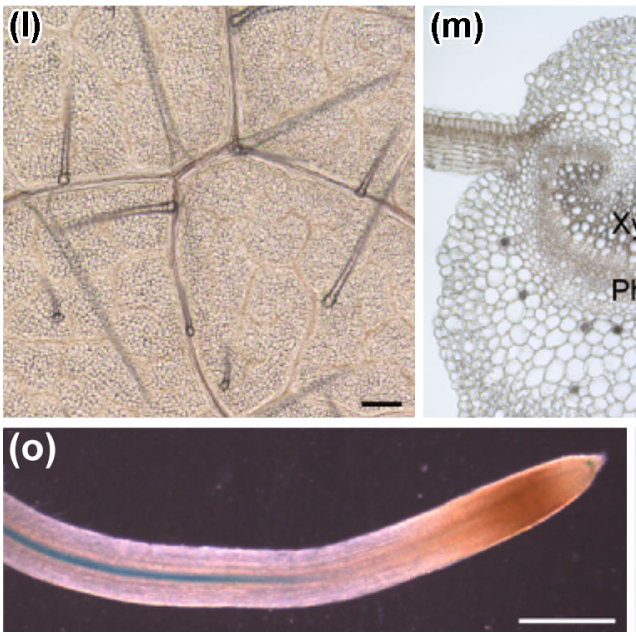

(j)

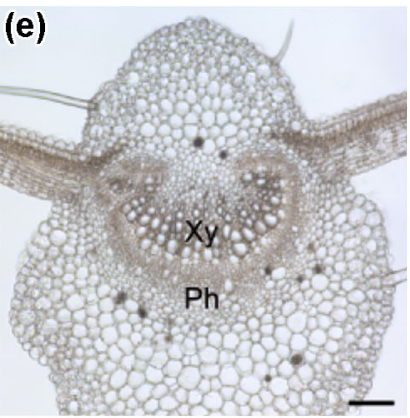

(h)
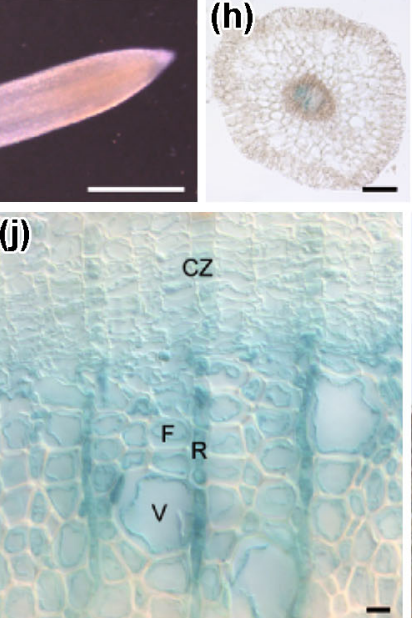

(k)

(m)

$-$

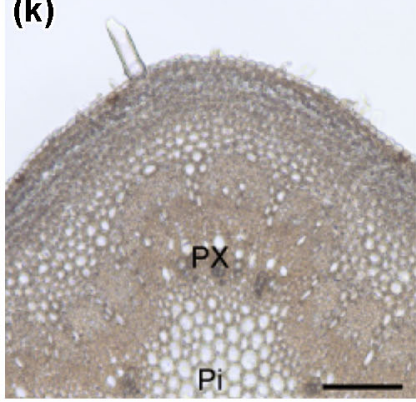

(n)
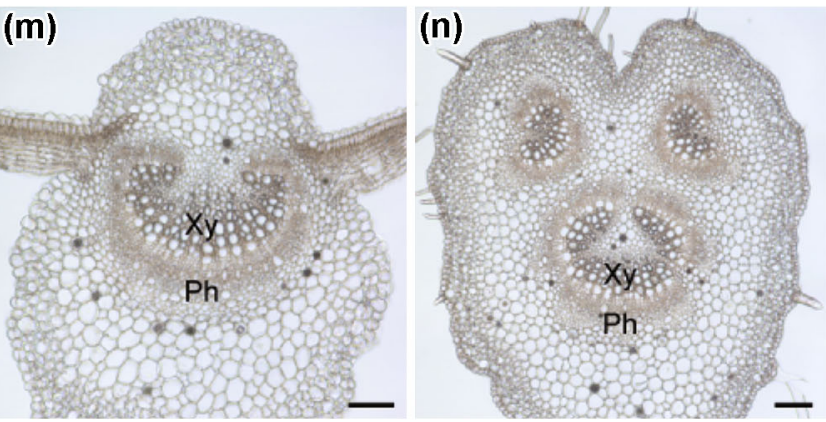

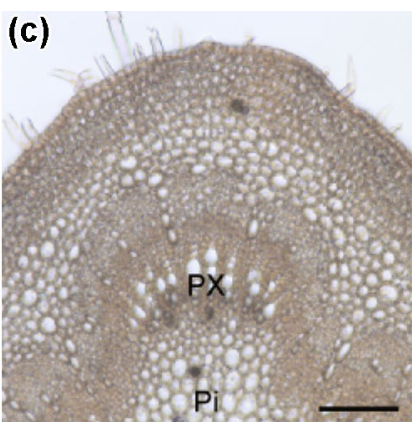

(f)

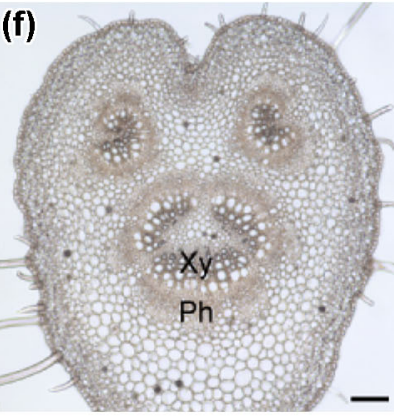

(p)

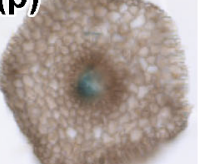


$\mathrm{h}, \mathrm{o}, \mathrm{p})$. The AtNST3/SND1 promoter was active in secondary xylem, phloem fibers and root xylem (Fig. 2a, b, g$\mathrm{j}, \mathrm{o}, \mathrm{p})$. However, no GUS staining was detected in other woody tissues such as primary xylem of young stems or the vascular system of leaves and petioles (Fig. $2 c-f, k-n$ ). The independent transgenic events, \#1 and \#3, showed similar GUS staining pattern in all tissues examined (Fig. 2). Taken together, our data indicate that the AtNST3/SND1 promoter has secondary woody tissue-dependent activity in hybrid poplar.

In developing secondary xylem, the AtNST3/SND1 promoter was active in wood fibers, vessel elements and ray parenchyma cells (Fig. 2b, j). In A. thaliana, AtNST3/ SND1 is predominantly expressed in secondary xylem fibers and differentiating vessel elements of the hypocotyl, and in interfascicular fibers of inflorescence stems [11, 12]. Thus, the AtNST3/SND1 promoter shows a similar cellspecific expression pattern in poplar. In the Populus genome, four NST/SND orthologues (VNSO9/WND2A/SND1$B 1, V N S 10 / W N D 2 B / S N D 1-B 2, V N S 11 / W N D 1 B / S N D 1-A 2$ and VNS12/WND1A/SNDI-Al) have been conserved and coordinately control secondary cell wall formation in xylem cells and phloem fibers [16-18]. Phylogenetically, VNSO9/WND2A/SND1-B1 and VNS10/WND2B/SND1-B2 are orthologous to A. thaliana NST1 and NST2, and VNS11/ WND1B/SND1-A2 and VNS12/WNDIA/SND1-A1 are orthologous to NST3/SNDI [16, 17]. The Populus NST/ $S N D$ orthologues are mainly expressed in wood fibers, developing vessels, xylem ray parenchyma cells and phloem fibers [16]. Interestingly, VNS11/WND1B/SND1$A 2$, an AtNST3/SND1 orthologue, was not detected by in situ hybridization in primary xylem of young stems and petioles [17]. The tissue-dependent expression of VNS11/ $W N D 1 B / S N D 1-A 2$ appears to be consistent with the GUS staining pattern in AtNST3/SND1pro::GUS-expressing poplar (Fig. 2). These results suggest that the transcriptional regulation of $N S T 3 / S N D 1$ orthologues could be evolutionarily conserved between herbaceous Arabidopsis and perennial poplar.

A tissue- and cell-specific promoter is an important and effective tool for precisely controlling the expression pattern of an effector gene for establishing a target trait in transgenic plants. Dozens of xylem tissue-dependent promoters have been identified in poplar and some are used for genetic modification of wood properties [5, 6, 15, 19-24]. Although woody tissue-specific promoters are highly expressed in mature xylem tissue, many show expression not only in secondary xylem but also in primary xylem and the vascular system of petioles and leaves [15, 19, 21, 23, 24]. The present study demonstrates that the AtNST3/SND1 promoter activity is dominant in secondary woody tissue of poplar trees. Using the AtNST3/SND1 promoter conjugated with a potent activator for secondary cell wall formation, we previously reported that transgenic hybrid poplar had a thicker secondary cell wall, higher xylem intensity and higher stem Young's modulus without any growth defects [14]. Together, the AtNST3/SND1 promoter is an option for expressing an effector gene only in secondary woody tissue to enhance the industrial value of wood.

Acknowledgements We are grateful to Ms. Shiho Kamikabeya and Ms. Maki Konnai in our laboratory for skillful technical support. This work was supported by the Advanced Low Carbon Technology Research and Development Program (ALCA) of the Japan Science and Technology Agency (JST) (to N.M. and T.T.).

\section{References}

1. Mosier N, Wyman C, Dale B, Elander R, Lee YY, Holtzapple M, Ladisch M (2005) Features of promising technologies for pretreatment of lignocellulosic biomass. Bioresour Technol 96:673-686

2. Min D, Li Q, Jameel H, Chiang VL, Chang HM (2012) The cellulase-mediated saccharification on wood derived from transgenic low-lignin lines of black cottonwood (Populus trichocarpa). Appl Biochem Biotechnol 168:947-955

3. Van Acker R, Leplé JC, Aerts D, Storme V, Goeminne G, Ivens B, Légée F, Lapierre C, Piens K, Van Montagu MC, Santoro N, Foster CE, Ralph J, Soetaert W, Pilate G, Boerjan W (2014) Improved saccharification and ethanol yield from field-grown transgenic poplar deficient in cinnamoyl-CoA reductase. Proc Natl Acad Sci USA 111:845-850

4. Baucher M, Chabbert B, Pilate G, Van Doorsselaere J, Tollier MT, Petit-Conil M, Cornu D, Monties B, Van Montagu M, Inze D, Jouanin L, Boerjan W (1996) Red xylem and higher lignin extractability by down-regulating a cinnamyl alcohol dehydrogenase in poplar. Plant Physiol 112:1479-1490

5. Wilkerson CG, Mansfield SD, Lu F, Withers S, Park JY, Karlen SD, Gonzales-Vigil E, Padmakshan D, Unda F, Rencoret J, Ralph J (2014) Monolignol ferulate transferase introduces chemically labile linkages into the lignin backbone. Science 344:90-93

6. Coleman HD, Yan J, Mansfield SD (2009) Sucrose synthase affects carbon partitioning to increase cellulose production and altered cell wall ultrastructure. Proc Natl Acad Sci USA 106:13118-13123

7. Chai G, Qi G, Cao Y, Wang Z, Yu L, Tang X, Yu Y, Wang D, Kong Y, Zhou G (2014) Poplar PdC3H17 and PdC3H18 are direct targets of PdMYB3 and PdMYB21, and positively regulate secondary wall formation in Arabidopsis and poplar. New Phytol 203:520-534

8. Zhao Y, Sun J, Xu P, Zhang R, Li L (2014) Intron-mediated alternative splicing of WOOD-ASSOCIATED NAC TRANSCRIPTION FACTOR1B regulates cell wall thickening during fiber development in Populus species. Plant Physiol 164:765-776

9. Joshi CP, Thammannagowda S, Fujino T, Gou JQ, Avci U, Haigler CH, McDonnell LM, Mansfield SD, Mengesha B, Carpita NC, Harris D, Debolt S, Peter GF (2011) Perturbation of wood cellulose synthesis causes pleiotropic effects in transgenic aspen. Mol Plant 4:331-345

10. Funahashi F, Ohta S, Taniguchi T, Kurita M, Konagaya K, Hayashi T (2014) Architectural and physiological characteristics related to the depressed growth of poplars overexpressing xyloglucanase in a field study. Trees 28:65-76

11. Zhong R, Demura T, Ye ZH (2006) SND1, a NAC domain transcription factor, is a key regulator of secondary wall synthesis in fibers of Arabidopsis. Plant Cell 18:3158-3170 
12. Mitsuda N, Iwase A, Yamamoto H, Yoshida M, Seki M, Shinozaki K, Ohme-Takagi M (2007) NAC transcription factors, NST1 and NST3, are key regulators of the formation of secondary walls in woody tissues of Arabidopsis. Plant Cell 19:270-280

13. Sakamoto S, Mitsuda N (2015) Reconstitution of a secondary cell wall in a secondary cell wall-deficient Arabidopsis mutant. Plant Cell Physiol 56:299-310

14. Sakamoto S, Takata N, Oshima Y, Yoshida K, Taniguchi T, Mitsuda N (2016) Wood reinforcement of poplar by rice NAC transcription factor. Sci Rep 6:19925

15. Takata N, Taniguchi T (2015) Expression divergence of cellulose synthase (CesA) genes after a recent whole genome duplication event in Populus. Planta 241:29-42

16. Zhong R, Lee C, Ye ZH (2010) Functional characterization of poplar wood-associated NAC domain transcription factors. Plant Physiol 152:1044-1055

17. Ohtani M, Nishikubo N, Xu B, Yamaguchi M, Mitsuda N, Goué N, Shi F, Ohme-Takagi M, Demura T (2011) A NAC domain protein family contributing to the regulation of wood formation in poplar. Plant J 67:499-512

18. Zhong R, McCarthy RL, Lee C, Ye ZH (2011) Dissection of the transcriptional program regulating secondary wall biosynthesis during wood formation in poplar. Plant Physiol 157:1452-1468
19. Chen C, Meyermans H, Burggraeve B, De Rycke RM, Inoue K, De Vleesschauwer V, Steenackers M, Van Montagu MC, Engler GJ, Boerjan WA (2000) Cell-specific and conditional expression of caffeoyl-coenzyme A-3-O-methyltransferase in poplar. Plant Physiol 123:853-867

20. Franke R, McMichael CM, Meyer K, Shirley AM, Cusumano JC, Chapple C (2000) Modified lignin in tobacco and poplar plants over-expressing the Arabidopsis gene encoding ferulate 5-hydroxylase. Plant J 22:223-234

21. Harding SA, Leshkevich J, Chiang VL, Tsai CJ (2002) Differential substrate inhibition couples kinetically distinct 4-coumarate:coenzyme a ligases with spatially distinct metabolic roles in quaking aspen. Plant Physiol 128:428-438

22. Stewart JJ, Akiyama T, Chapple C, Ralph J, Mansfield SD (2009) The effects on lignin structure of overexpression of ferulate 5-hydroxylase in hybrid poplar. Plant Physiol 150:621-635

23. Ko JH, Kim HT, Hwang I, Han KH (2012) Tissue-type-specific transcriptome analysis identifies developing xylem-specific promoters in poplar. Plant Biotechnol J 10:587-596

24. Ratke C, Pawar PM, Balasubramanian VK, Naumann M, Duncranz ML, Derba-Maceluch M, Gorzsás A, Endo S, Ezcurra I, Mellerowicz EJ (2015) Populus GT43 family members group into distinct sets required for primary and secondary wall xylan biosynthesis and include useful promoters for wood modification. Plant Biotechnol J 13:26-37 